\title{
PROLEGOMENA TO A HISTORY OF STORY-TELLING AROUND THE BALTIC SEA, C. 1550-1800
}

\section{Jürgen Beyer}

The following essay was originally presented to a folkloristic conference devoted to the "Documentation and Analysis of Baltic Mentality" $(\underline{* 1})$ and was designed to fulfill three purposes: It was to serve as a historical introduction to the theme of the conference, draw attention to some methodological problems and propose avenues for future research. The revised version published here still follows the original line of thought without any attempt to discuss all questions exhaustively. ( $(\underline{2})$

\section{I.}

German- and Dutch-speaking folklorists have conducted a substantial amount of research in recent years on the background of the nineteenth-century collections of folk narratives, while their colleagues in North America and Scandinavia have preferred to concentrate on the interpretation of these texts without concerning themselves too much with the question of how the sources came into being. The leading figure in German research has been Rudolf Schenda, whose well-written and provocative outline of the history of story-telling in Europe questions many long-standing assumptions of folkloristic research. $(\underline{* 3})$

It is by now well-known that the works of the Grimm Brothers triggered the large-scale collecting of folk narratives of the nineteenth and early twentieth centuries. However, the Grimm Brothers' own collections (Kinder- und Hausmärchen, 1812-15, Deutsche Sagen, 1816-18), despite claims to the contrary, are for the most part not collected from the "folk" but are derived from bourgeois and literary sources of various kinds. $(\underline{* 4})$

Although the concepts of folk narrative and of its genres (legend, fairy tale, etc.) were an invention of the Grimm Brothers and their disciples, there can be no doubt that tales (which we today would classify as folk narratives) were spread orally and in writing prior to the age of romanticism. What were these stories and how were they told? Rudolf Schenda has shown us the lead, but a detailed history of story-telling remains to be written. The amount of data to be processed for all of Europe is far too large to be handled by an individual scholar, whereas the study of a small region $(* 5)$ might be too specific to reach conclusions valid for research in general. Work concentrating on the Baltic Sea area, however, promises to be very rewarding, while still being manageable in size.

The classic example of a study of culture around a sea is the book on the Mediterranean by Fernand Braudel, La Méditerranée et le monde méditerranéen à l'époque de Philippe II , published for the first time in $1949,\left({ }^{*} 6\right)$ dealing among other things with the physical geography, the climate, the means of communication and the economy of the region. A similar line of enquiry, concerning the North Sea, is now being pursued by the Dutch scholar Lex Heerma van Voss. (*7) In the following I shall restrict myself to two unifying factors of immediate relevance for folk narratives, that is, religion $(\underline{* 8})$ and language. 
By the end of the Middle Ages all countries around the Baltic Sea had converted to Christianity. Apart from the easternmost shores under Russian influence all coastal areas were subjected to the authority of the Pope in Rome. In the sixteenth century almost all of these areas adopted the Wittenberg Reformation. Only Lithuania (in the period dealt with here not bordering on the Baltic Sea) and large parts of Poland (with the exeption of territories like Prussia, Courland, Danzig and most areas bordering on the Baltic Sea) remained Catholic. Lutheranism extended also beyond the shores of the Baltic Sea, to the Northwest until Iceland and to the South into Germany.

The second unifying factor was language. Latin as the language of the church and learned exchange $(* 9)$ was a legacy of the Western medieval church - but this was common to all of Western Europe. Much more important as a lingua franca was Low German. It was the language spoken by Hanseatic merchants but was also used by craftsmen and the administration of the Scandinavian kingdoms. From the sixteenth century onward it was increasingly being replaced by High German, first in writing and later (but not entirely) in oral communication.(*10) Again, Low German was also spoken (and understood) outside the Baltic Sea area, notably along the Southern shores of the North Sea.

An analysis on the lines of Braudel or Heerma van Voss (who includes the Western part of the Baltic Sea into his concept of North Sea culture) would show many traits that were common to most of the Baltic Sea area without being exclusive to the area. Some traits would be shared with areas to the West, others with areas to the South, etc. Another question which could be raised is how far cultural phenomena stretched inland and among which social groups they were to be found. However, a general picture of the Baltic Sea area would still show that there was a bundle of unifying factors quite distinct as a whole from that of other areas. Two items in this bundle were religion and the lingua franca.

The dissolution of the Soviet Union has made it possible again to focus on a common heritage and not least - on common problems to solve in the countries around the Baltic Sea. However, already in the seventeenth century the area was viewed as a unity by some writers. In 1624 Niels Heldvad (about whom more below) thought that the circulus balticus was composed of the following countries: Denmark, Norway, Sweden, Livonia, Courland, Prussia, Pomerania, Mecklenburg, Holstein and Schleswig.(*11) This list calls for some explanation. The West Swedish province of Bohuslän belonged to Norway in Heldvad's time, justifying that country's inclusion in the list. Heldvad did not mention Finnland because he probably saw it as part of Sweden, which ruled all coastal areas around the Gulf of Finland. Russia and Lithuania did not border on the Baltic Sea and could therefore be omitted. Poland, however, did so. It might have been beyond Heldvad's horizon because of the foreign language spoken there or because of the foreign religion practised by the majority of its inhabitants (although the coastal areas were mainly inhabited by Lutherans).

The populations around the Baltic Sea were neither static nor ethnically homogeneous. German merchants settled in towns like Visby, Riga, Tallinn (Reval), Vyborg (Wiborg, Viborg, Viipuri), Stockholm, etc., soon to be followed by craftsmen. The German percentage of the town population around the Baltic Sea was high. In some areas the Germans assimilated more or less quickly with the local population, while in a number of towns (mainly in Livonia and Courland) they retained a hold on political power throughout the entire early modern period.(*12) Although Germans were the largest group of foreign immigrants, they were not the only one. Dutch immigrants settled in the Baltic Sea area, as did Scots, Walloons and other groups. (*13) In the towns on the eastern shores of the Baltic Sea there were also Russian inhabitants. $(* 14)$ 
Migrants did not only come from the West. Finns looked for a livelihood in Sweden and Estonia, while Swedes settled in Finland and Estonia. Danes, however, seem only to a rather small extent to have settled those areas around the Baltic Sea that once were under Danish rule (Gotland, Rügen and parts of Estonia).

As a consequence of these migrations, there were numerous foreign language churches within the Lutheran state churches of the area (German congregations in most larger towns, Finnish churches in Sweden, Swedish churches in Finland and Estonia). Until the seventeenth century, however, there were only very few non-Lutheran churches for foreigners in the area (e. g. for Russians in Tallinn).

We have to reckon with a fair degree of bi- and trilingualism. We should also remember that around 1700 only in a few areas was the language of administration spoken by the majority of the population. This was the case in the Polish-speaking areas of Poland, in Denmark (though not in the dependent territories) and in those parts of Sweden that had not been taken from Denmark Norway. The Low - German speaking areas as well as Estonia and Latvia had to cope with a High German administration, Lithuanians with a Polish one and Finns with a Swedish one.

To conclude, there were ample possibilities for cross-fertilization, both through personal contacts and through the cultural innovations introduced by trade (e. g. of books).(*15) This has long been recognized in the field of linguistics: Etymological dictionaries for the languages around the Baltic Sea list many loanwords from Low or High German and show other influences as well, notably the impact of Swedish on Finnish. Recently it has also been argued that eating habits still are influenced by the Hanseatic past. $(\underline{* 16})$

\section{II.}

Already in the early days of folkloristics as an academic discipline the question of the migration of tales was discussed vividly. The many languages of the Baltic Sea area do not seem to have presented barriers for the migration of stories. On the contrary, tales seem to have travelled as widely in the area as people and merchandise.

I should like to highlight this with some examples drawn from the work of Niels Heldvad (or Nicolaus Helduaderus) (1564-1634).(*17) Heldvad took his name from his home village Hellevad (German: Hellewatt) in the northern part of the Duchy of Schleswig. After attending grammar schools at Flensburg, Haderslev (Hadersleben), Luneburg and Lubeck, he spent a year in Riga and the surrounding area (1586/87), mainly working as a private tutor. He continued his education at Rostock University until 1590 when he was appointed to succeed his father as pastor of Hellevad. Due to Heldvad's opposition against the Calvinizing policies of the ducal government, he lost his post in 1611. From 1616 onward he earned his living in Copenhagen as royal calendar and almanac maker and wrote books on diverse subjects. Heldvad published in the literary languages current in his home village and in Copenhagen, that is, Danish, High German and Low German. Of his many publications, a High German book of 1624 is devoted to the history of the countries around the Baltic Sea, the circulus balticus. A rather superficial perusal already shows that many of the stories told would today qualify as folklore. Here is an example: 
Am PalmSontag [1623] / war der 6. Aprilis / ist die vornehme Kauff: vnnd Handelstadt Bergen in Norwegen / vnter der Predigt vnnd dem Gottesdienst / durch Vnachtsamkeit einer BrandtweinKrügerschen / mit Fewer angesteckt / vnnd gleich wie Sodoma in einer Eyl zergangen / vnd alles in die Asche geleget $\left(*_{18}\right)$ / welches eine grewliche Straffe GOttes gewesen.(눈)

On Palm Sunday, 6 April [1623], the notable commercial town of Bergen in Norway caught fire during the sermon and the divine service through the negligence of a female publican, and perished in a hurry like Sodom, and everything was turned to ashes, which was a terrible punishment of God."

A similar story is told in Theatrum Europceum, compiled in Frankfort-on-the-Main mainly on the basis of newspapers and pamphlets. Here we read:

In dem April hat die Statt Bergen in Norwegen durch Fewers Noth grossen Schaden erlitten / welcher auff viel Tonnen Gold geschätzet worden: In dem diese Statt fast gantz sampt der Kirchen in die Aschen gelegt worden / vnnd weil die Häuser fast alle Höltzern gewesen / hat der Brand desto schrecklicher vnd geschwinder vberhand genommen. (ㄴ20)

In April the town of Bergen in Norway suffered great damage through fire. The costs were estimated to amount to many tons of gold. Almost the entire town including the church was turned to ashes, and since nearly all houses were built of wood, the fire could ravage all the more terribly and quickly.

The text explains the rôle of Bergen in Norwegian trade and gives a reason for the fire: The German merchants in Bergen, fearing that their numbers would increase too much, had devised several "games" newcomers had to play. In this way they wanted to deter rich milksops from joining them. The "games" included whipping the newcomers, throwing them into the sea, pulling them with ropes under the keel of a ship and hanging them in a basket above an intensely smoking fire. Occasionally, candidates had died under the procedure, which had led a pastor to prophesy God's punishment for this cruel treatment. $(\underline{* 21})$

The explanation of the conflagration as God's punishment which we already find in Heldvad's book is here much more detailed. The German merchant colony in Bergen was notorious for the rough "games" played with newcomers. Despite several orders from the authorities, these initiation rites continued to be practised until the second half of the seventeenth century. $(* 22)$

It has as yet not been possible to trace the source for these two accounts. In Heldvad's case it is conceivable that he had heard oral news in Copenhagen. In the case of the Theatrum Europceum it seems more likely that the story is based on some written news report. $(* 23)$ It is clear, however, that the reports contain traditional elements. Ever since the destruction of Sodom and Gomorrah evil-doing towns were said to have been destroyed by God's wrath.(*24) New reports of this type were still appearing in Heldvad's day. In the year of his birth several towns were reported to have been destroyed. ( $(25)$ At about the same time two Saxon prophetesses referred to an "old prophecy about how Freiberg shall sink into the earth and Dresden shall drown".(*26) When Heldvad was twelve years old, the town of Timisoara in present-day Romania was reported to have disappeared. 
(*27) From the year that Bergen was destroyed we have the probably oldest detailed version of a tale telling about the destruction of Rungholt on the West coast of the Duchy of Schleswig, due to the ungodliness of its inhabitants. $(\underline{* 28})$ Three years after the publication of Heldvad's book a school-boy held a penitential sermon from the church-tower at Jönköping. One of his prophecies was that Jönköping would sink into the earth if its inhabitants did not repent.(*29) Most of these stories have in common that they interprete current events through the lenses of a narrative tradition.

It would be worth-while to analyse Heldvad's entire book with the methods of historical narrative research (Historische Erzählforschung), while at the same time paying attention to what he included under the concept of circulus balticus. It seems likely that he only collected items available in the languages he could read (in addition to the languages he published in, at least Swedish and Latin), thus leaving out publications in Polish. In Heldvad's days, there was hardly anything printed in Lithuanian, Latvian and Estonian, and books in Finnish mostly contained basic religious texts which he was well acquainted with in his own languages. Heldvad's selection of suitable material seems also to have been influenced by his origins, with special emphasis being placed on the Duchies of Schleswig and Holstein and the Kingdom of Denmark-Norway. It will also be possible to recognize his confessional standpoint: whole-heartedly Lutheran, vehemently anti-Calvinist and comparatively friendly to the Catholic tradition.

Heldvad's writings serve also as a useful reminder of the traps we should be aware of when dealing with nineteenth-century collections of folk narratives. His works are among the sources of Just Mathias Thiele's collection of Danish legends from the first half of the nineteenth century.(*30) One of the so-called legends is taken from a Danish book of 1618 containing stories related to the ecclesiastical calendar, in which Heldvad tells many well-known stories from the European tradition without adapting them to local circumstances.

I shall quote Heldvad's version which he enters under St. Martin's Day, 11 November. After telling the legend of St. Martin as well as referring to the eating customs connected to the day, he adds:

Men det drog sig oc en gang til / at en slem / Gudsfragangene / Tiuffactige Møller / som icke vilde søge Christelig oc AErlig samquem / met sine Naboer / men gick til Møllen / der hans Naboer ginge til Gilde / at forsøge Bondens Sacke huad de formaatte / thi hannem siuntes at hand haffde nu best leylighed til at bruge sine Tiuffactige Hoender / effter sin gamle vijs oc vane. Huad skede? Dieffeluen kom Liffactig til hannem / vdi Møllen / oc sagde: Volan Staldbroder / huad giør du? ieg forstaar du sysler i fremmede Poser / wi ville nu en gang maale tilsammen / huorledis det vil skicke sig. Dermet opløffte hand Møllestenen / oc stack Mølleren der vnder / drog saa Stiffborden oc Møllen løs / oc maalede hannem saa smaa som Mask. Der dette rycte spurdis offuer det gantske Land / oc alle omliggende Grentzer / da forsuorede Møllerne hannem / saa at ingen Erlig Møller mand maaler Korn paa S. Mortens dag.( $(\underline{31})$

But it happened also once that a bad, godless and thievish miller, who did not want to have Christian and honest company with his neighbours, went to the mill while his neighbours went to a feast. He investigated the peasants' sacks since he thought that he now had the best opportunity to use his thievish hands after his old way and custom. What happened? The Devil appeared in person to him in the mill and said: Good friend, what are you doing? I understand that you are working in foreign pockets. Let us now mill together and see how 
that will go. He lifted the millstone, put the miller under it, opened the sluice gate, started the mill and ground him to pieces. When this rumour spread over the whole country and all neighbouring areas, the millers disowned him. The result is that no honest miller will work on St. Martin's Day.

Thiele retells the story with only minor variations in the first edition of his collection, $(* 32)$ and again, stylistically somewhat reworked, in the second edition.(*33) In 1845, Karl Müllenhoff published a collection of Schleswig-Holsteinian legends and fairy-tales which also contains this story. His rendering is a translation from Thiele's second version, again with a few variations. $(* 34)$

Müllenhoff's reason for including this tale was probably that the original author was born in the Duchy of Schleswig. It should be noted though that not even the nineteenth-century versions fix the story to a specific locality. However, ever since then, the tale has figured as a Danish or SchleswigHolsteinian folk narrative.

\section{III.}

A study of Heldvad alone obviously would not solve the questions raised at the outset. A study of other kinds of sources such as secular and ecclesiastical archival records, $(* 35)$ autobiographies, $($ *36) travel accounts, $(* 37)$ miracle reports, $(* 38)$ peasant diaries, $(* 3939)$ funeral tales $(* 40)$ or pamphlets $(* 41)$ should make it possible to investigate how people told tales around the Baltic Sea in the period from about 1550 to 1800 . It should also be possible to determine in what way tales influenced people's actions and their perceptions of reality. Inevitably, many of the tales to be analysed in this way will not be covered by the narrow definitions of folk narrative developed in the nineteenth century.

I shall take the second suggestion first: One example of how tales influenced the perception of reality is the story about Sodom and Gomorrah and the fire in Bergen. Another example is ghoststories. In pagan times a meeting with ghosts was very dangerous, in the Middle Ages they developed into less threatening souls returning from purgatory, and after the Reformation they fulfilled new functions, which theologically were quite difficult to explain. At any time, however, a mysterious meeting in a dark place would be interpreted according to stories heard before.

Secondly, how did people tell stories and how did they regard these stories? I should like to draw a very rough sketch of developments as I can discern them at the moment: Obviously, since time immemorial people have talked to each other and told stories about things that have happened. Even though indices of motifs and types contain references to medieval texts, (*42) I should like to doubt if these texts were perceived as fiction by their authors and the medieval readers (or listeners). Lutheran theologians distinguished between historice and fabulce. Exempla told by a pastor were historice (true and useful stories), but miracles told in Catholic literature were fabulce (invented and harmful lies) - Catholics, of course, viewed the matter the other way round. The main category was Truth, not a modern division into genres. The term historia clearly also covered stories we today would call history, but it is rather telling that a historico-topographical work of the late sixteenth century could be concluded with an "index ... according to the Ten Commandments ... for the benefit of poor pastors who cannot afford the large Promptuaria Exemplorum". In other words, it was being prepared for use in sermons. $(\underline{* 43})$ 
It is my impression that oral prose tales (which later came to be called legends or fairy tales) in the early modern period were told as real events. Tales about supernatural beings, although containing well-known motifs and types, were told as memorates. We should remember that the boundaries between real and unreal or credible and uncredible were drawn differently by people in those days than by nineteenth- and twentieth-century academics.

It was only in the course of the eighteenth century that things began to change. The eighteenth century was the period in high culture in which fictional literature (mainly novels) became firmly established in the book-market. Reading habits changed as well: Instead of studying few books intensively, readers started to read many books more cursorily and only once. Reading societies were founded, printing presses were established in the provinces, and the authorities conceded a limited freedom of the press. (*44) It was at this time that fictionalised tales - which earlier had been rejected on religious grounds $(* 45)$ - started to reach a larger section of society. This was also the period when the words for legend and fairy-tale in the Germanic languages took on their present meaning.( $(\underline{46})$

The Grimm Brothers concentrated and codified literary developments of the late eighteenth century.(*47) With the publication, translation and imitation of the Kinder- und Hausmärchen, as well as with the sale of individual fairy tales as cheap booklets, a new literary taste spread among the lower classes, which earlier only had had access to Luther's Small Catechism, the official hymnal, almanacs, penny godlies and penny dreadfuls. $(* 48)$ The collections in folklore archives therefore only document - and this may sound rather banal - the folk narratives of the period of collection. These were not stories that had been handed down unchanged by the fire-side by word of mouth since time immemorial but only records of more or less oral performances which were the result of formal (compulsory school attendance) $(\underline{* 49})$ or informal literary training only available since the nineteenth century.

A history of story-telling around the Baltic Sea in the period from about 1550 to 1800 will show how the corpus of folk narratives and the concepts of genres developed through the centuries and how both drastically changed at the time of the Grimm Brothers. It will not only reveal to what extent there were similarities, differences and influences between the regions concerned but also how they were caused.

I should like to argue that similarities in folk narratives around the Baltic Sea are less due to a common geography but more to a common religion and a lingua franca. The fact that the Baltic Sea to a large extent was a mare lutheranicum enabled the same kind of stories to be spread in populations with similarities in reading habits and formal or informal modes of censorship. This is most obvious for the field of religious narratives, but I think it had an important influence on secular narratives as well.

A meaningful analysis of narratives in the folklore archives must be based on a clear awareness of these developments. 


\section{References}

1. Held at Visby, Gotland, 23-24 May 1997, under the auspices of the Gotland Centre for Baltic Studies.

2. Discussions with Michael Chesnutt (Copenhagen) and Michael Driedger (Mainz), both of whom remain critical of different parts of my argument, have helped me clarify my position.

3. Rudolf Schenda: Von Mund zu Ohr. Bausteine zu einer Kulturgeschichte volkstümlichen Erzählens in Europa, Goettingen 1993; cf. my review in: Historische Zeitschrift 261 (1995), p. 108111; cf. also Rudolf Schenda \& Hans ten Doornkaat (eds.): Sagenerzähler und Sagensammler der Schweiz. Studien zur Produktion volkstümlicher Geschichte und Geschichten vom 16. bis zum frühen 20. Jahrhundert, Berne \& Stuttgart 1988.

4. Kinder- und Hausmärchen, 4 vols., ed. Hans-Jörg Uther, Munich 1996; Deutsche Sagen, 3 vols., ed. Hans-Jörg Uther \& Barbara Kindermann-Bieri, Munich 1993; Heinz Rölleke: Wo das Wünschen noch geholfen hat". Gesammelte Aufsätze zu den Kinder- und Hausmärchen" der Brüder Grimm (=Wuppertaler Schriftenreihe Literatur, vol. 23), Bonn 1985.

5. Cf. the thorough study of West Frisia by Jurjen van der Kooi: Volksverhalen in Friesland. Lectuur en mondelinge overlevering. Een typencatalogus (diss. Groningen) (=Estrikken, vol. 63; =Nedersaksische Studies, vol. 6), Groningen (1984).

6. 2 vols., Paris 31976.

7. Lex Heerma van Voss: North-Sea Culture, 1500-1800, in: id. \& Juliette Roding (eds.): The North-Sea and Culture (1550-1800), Hilversum 1996, p. 21-40.

8. Cf. Wolfgang Brückner (ed.): Volkserzählung und Reformation. Ein Handbuch zur Tradierung und Funktion von Erzählstoffen und Erzählliteratur im Protestantismus, Berlin 1974; id.:

Konfession, Konfessionen, in: Enzyklopädie des Märchens, vol. 8, Berlin \& New York 1994-96, col. 116-122.

9. Nova literaria maris balthici \& septentrionis collecta Lubecæ 1698-1708; Outi Merisalo \& Raija Sarasti-Wilenius (eds.): Mare balticum - mare nostrum. Latin in the Countries of the Baltic Sea (1500-1800) (=Suomalaisen tiedeakatemian toimituksia / Annales academiæ scientiarum fennicæ, Ser. B, vol. 274), Helsinki 1994.

10. Vibeke Winge: Dänische Deutsche - deutsche Dänen. Geschichte der deutschen Sprache in Dänemark 1300-1800 mit einem Ausblick auf das 19. Jahrhundert (=Sprachgeschichte, vol. 1), Heidelberg 1992; Kurt Erich Schöndorf, Kai-Erik Westergaard \& Karl Hyldgaard-Jensen (eds.): Niederdeutsch in Skandinavien. Akten des 1. nordischen Symposions Niederdeutsch in Skandinavien" in Oslo 27. 2. - 1. 3. 1985 (=Beihefte zur Zeitschrift für deutsche Philologie, vol. 4), Berlin 1987. Several valuable conference proceedings on "Niederdeutsch in Skandinavien" have followed.

11. Nicolaus Helduaderus [Heldvad]: SYLVA CHRONOLOGICA CIRCULI BALTICI, Das ist: Historischer Wald / vnnd Vmbzirck deß Baltischen Meers oder der OstSee ... Die Denckwirdigste 
Geschichte / so sich in Dennemarck / Norwegen / Schweden / Lieffland / Churland / Preussen / Pommern / Meckelnburg / Hollstein / Schleßwig / vnd dero anstossenden Ländern / Städten vnd Ortern zugetragen ..., 2 vols., Hamburg 1624. Nova literaria (cf. n. 9) collects literary news from a similar list of countries.

12. Paul Johansen \& Heinz von zur Mühlen: Deutsch und undeutsch im mittelalterlichen und frühneuzeitlichen Reval (=Ostmitteleuropa in Vergangenheit und Gegenwart, vol. 15), Cologne \& Vienna 1973; Allan Tønnesen: Helsingørs udenlandske borgere og indbyggere ca. 1550-1600 (=Byhistoriske Skrifter, vol. 3), Ringe 1985; Winge (cf. n. 10); Robert Schweitzer: Die Wiborger Deutschen (=Saksalaisen kulttuurin edistämissäätiön julkaisuja, vol. 3), Helsinki 1993.

13. Tønnesen (cf. n. 12); Vibeke Winge: Zur Sprache und Geschichte der niederländischen Bauern auf der Insel Amager bei Kopenhagen, in: Hubertus Menke (ed.): Die Niederlande und der europäische Nordosten. Ein Jahrtausend weiträumiger Beziehungen (700-1700). Vorträge. Symposium Kiel, 8.-11. Oktober 1989 (=Landesforschung, vol. 1), Neumünster 1992, p. 329-337; Winge (cf. n. 10), p. 335-345; Ole Peter Grell: Huguenot and Walloon contributions to Swedens's emergence as a European power, 1560-1648, in: Proceedings of the Huguenot Society 25 (1992), p. 371-384.

14. Schweitzer (cf. n. 12); Arnold Soom: Der Handel Revals im siebzehnten Jahrhundert (=Marburger Ostforschungen, vol. 29), Wiesbaden 1969.

15. Cf. also Lex Heerma van Voss: Trade and the Formation of North Sea Culture, in: Northern Seas Yearbook 1996, p. 7-19

16. Günter Wiegelmann \& Ruth-E. Mohrmann (eds.): Nahrung und Tischkultur im Hanseraum (=Beiträge zur Volkskultur in Nordwestdeutschland, vol. 91), Münster \& New York 1996.

17. Cf. H[ans] V[aldemar] Gregersen: Niels Heldvad. Nicolaus Helduaderus. En biografi (=Skrifter, udgivne af Historisk samfund for Sønderjylland, vol. 17), Copenhagen 1957; id. \& R[ichard] Paulli: Heldvad, Niels, in: Dansk biografisk leksikon, vol. 6, Copenhagen 1980, p. 206 sq.

18. The fire - though severe it was - did not destroy the entire town ([Mikel Hofnagels] optegnelser. 1596-1676, in: N. Nicolaysen (ed.): Norske Magasin, vol. 2, Christiania 1868, p. 165-233, here p. 187 sq.).

19. Heldvad (cf. n. 11), vol. 2, p. 320 sq.

20. THEATRUM EUROP ÆUM ..., [vol. 1,] ed. Johann Philipp Abelinus, Frankfort-on-the-Main 1662 (1635), p. 787.

21. Ibid.

22. Julius Harttung: Die Spiele der Deutschen in Bergen, in: Hansische Geschichtsblätter 1877, p. 87-111; Karl Koppmann: Herluf Lauritssön's Bericht über die Spiele der Deutschen zu Bergen, ibid., p. 140-143. 
23. Haakon Fiskaa: Skrevne og trykte nyhetsblad. Katalog over blad fra og om Norge dessuten over trykte blad fra andre land i Universitetsbiblioteket i Oslo, Oslo 1934, does not mention any pamphlet concerning the conflagration in 1623.

24. Cf. Will-Erich Peuckert: Sodom und Gomorrha, in: Handwörterbuch des deutschen Aberglaubens, vol. 8, Berlin and Leipzig 1936-37, col. 21-25; Marianne Beth: Ungastlichkeit, ibid., col. 1415 sq.

25. Ein grausame vnd erschreckliche geschicht vnd zeitung / der grossen vnd zuuor vnerhörten Erdbiebung / in deß Hertzogen von Sophoien Lande / in welchem sieben Stedte vntergangen vnd versuncken / nicht weit von Nißa gelegen / diß M.D.LXIIII. Jar geschehen ..., Prague 1564; Erschreckliche vnd jemmerliche Zeittung / Wie etzliche Stedte vnd Dörffer / in des Hertzogen von Sophoia Landt / mit sampt dem Volck darinnen / versuncken vnd vntergangen seindt. Andere Zeittungen: Von der grausamen vnd vngestümmen zerstörung der Stadt Cattaro / welche mit sampt den vmbligenden Flecken vnd Bergen / in einem grossen Erdbiedem / zerschüttert vnd zerfallen ..., n. pl. 1564; Schrecklike Vnde warhafftige jamerlike Tydinge / wo etlike Steede vnde Dörper / jn des Hertigen van Sophoia Landt / sampt dem Volcke darinne / in dem vorschenen LXiiij. Jare jm Augusto vorsuncken vnd vnder gegan sint. Noch ander Tydinge / van der gruwsamen vnde vngestümigen vorstöringe der Statt Cattaro in Slauonien / welcker sampt den vmmeliggenden Bleken (sic) vnde Bergen / jn ener groten Erdtbeuinge tho schüddet vnde thouallen sint ..., n. pl. n. d.

26. Newe Zeytung. Von einem Megdlein das entzuckt ist gewest / vnd was wunderbarliche Rede es gethan hat / geschehen zu Freyberg in Meyssen im Jar. M.D.LX., Nuremberg n. d., f. A2r, quotation f. A4v: "alte Prophezeyung / wie Freyberg sollen versincken / vnd Dressen ertrincken";

Wundergeschicht / Offenbarung vnnd Gesichte / einer entzuckten Kindsbetterin / welche ... Land Leut vnd stette zur busse vermanet / geschehen zur Neünstatt dises 1569. Jars / Den fünff vnd zweintzigsten December, Augsburg n. d., f. B2v.

27. Warhafftige vnd erschreckliche Newe Zeitung auß Vngern von der Stadt Temesuar / zu jetziger zeit Türckisch / durch verhengknuß Gottes / gantz in grundt verderbt vnd versencket ist, Nuremberg (1576), in: Walter L. Strauss: The German Single-Leaf Woodcut 1550-1600. A Pictorial Catalogue, New York 1975, p. 122; En sandru / gruelig oc forskreckelig ny Tidende aff Vngern / huorledis den Stad Temesuar / som nu horde Tyrckeren til / formedelst Guds synderlige tilladelse / bleff i it Øyeblick slet oc aldelis fordærffuet / omstyrt / forsprengt oc nedsiuncken / Oc der som Staden oc Slottet stod tilforn / er nu ekon idel Vand / oc er ligest til at ansee som en stor Sø, Copenhagen 1576; Ein erschrecklich Newes Liedt aus Vngern / von der Stadt Temesuar (jetziger zeit Türckisch) wie die von Tausent vnd vier hundert Centner Puluers ist zu grund gangen. Im Thon. Kompt her zu mir / spricht Gottes Sohn. Gemacht im M.D.LXXVI. Jar / den XXVII. Maij. Erstlichen / Gedruckt zu Prag bey Michel Peterle, n. pl. n. d.

28. O. Hartz: Die Rungholtsage bei den nordfriesischen Chronisten, in: Jahrbuch des Nordfriesischen Vereins für Heimatkunde und Heimatliebe 20 (1933), p. 80-86.

29. Joannes Baazius: CONCEPT Aff Een Christeligh Bootpredikan / Som itt olärdt Scholæbarn framförde / vthi Jönekiöpingz Kyrkio Torn then 30. April Åhr 1627. Effter wisse witnes berättelse / som tilhörde: Sammanschriffuen, Kalmar 1627; id.: Inventarium ecclesiæ sveogothorum ..., Linköping 1642, p. 765-770; Petrus Jonae: Een liten Förklaring / På then Predikan / Som een 
Dieckne Poike hafft haffuer vthi Jenekiöpingh Anno 1627. in Aprili vthaff Kyrcke Tornet som förestår. Hastelighen Schriffuen, Kalmar 1627.

30. J[ust] M[athias] Thiele: Danske Folkesagn, 4 parts, Copenhagen 1818-23; 2nd ed. with the title: Danmarks Folkesagn, 2 vols., Copenhagen 1843.

31. Nicolaus Heldvaderus: CALENDARIOGRAPHIA SACRA ... Disligest en Kircke Calender, paa huad Aar oc Dag / Guds Helligen haffue beseglet / Christi Euangelium / met deris Blods vdgydelse ... effter som deris Naffne findis i voris Aarlige Allmanach, n. pl. 1618, f. Aaa4v sq.; repeated verbatim in id.: HISTORIARUM SACRARUM ENCOLPODION Det er / En Nye og Nyttig Bog / om vor HErris JEsu CHristi / Sampt hans hellige Apostlers / Confessorum oc Martyrers Liff oc Leffnets Historie / vdi huilcken findis Aaret / Maaneden oc Dagen / paa huilcke alting er skeed ..., Copenhagen 1634, f. Bbbbb2r.

32. Thiele (cf. n. 30), 1823, part 4, p. 107 sq.

33. Thiele (cf. n. 30), 1843, vol. 2, p. 79.

34. Karl Müllenhoff: Sagen Märchen und Lieder der Herzogthümer Schleswig Holstein und Lauenburg, Kiel 1845, p. 151, no. 206.

35. Cf. Inger Lövkrona: "Det är bestämt en byting". Dordi Larsdotter och hennes vanföra barn. En studie utifrån ett gotländskt domstolsfall, in: Budkavlen 68 (1989), p. 5-18; Jan-Inge Wall: Hon var en gång tagen under jorden ... Visionsdikt och sjukdomsbot i gotländska trolldomsprocesser (=Skrifter utg. genom Dialekt- och folkminnesarkivet i Uppsala, Ser. B, vol. 19), Uppsala 1989.

36. Cf. Harald Ilsøe: 555 danske Selvbiografier og Erindringer. En kronologisk forer med referater til trykte selvbiografier forfattet af personer født før 1790, Copenhagen 1987.

37. Cf. Samuel E. Bring: Itineraria Svecana. Bibliografisk förteckning över resor i Sverige fram til 1950 (=Svenska bibliotekariesamfundets skriftserie, vol. 3), Stockholm 1954; Harald Ilsøe:

Udlændinges rejser i Danmark indtil år 1700. En bibliografisk fortegnelse, Copenhagen 1963.

38. Cf. Karl-Sigismund Kramer: Brauch, Sage, Glaube und Predigtmärlein" in einem Mirakelbuch der heiligen Anastasia zu Benediktbeuren, in: Fabula 32 (1991), p. 119-131; Jürgen Beyer: Aspects of the Transformation of Visionary Narratives in Scandinavia and Germany, c. 1400-1700, in: Birgitte Rorbye (ed.): Visions - Narratives About the Past, the Present and the Future (working title), 1997 (forthcoming).

39. Cf. Bjorn Poulsen: Om 1600-tallets bonder og deres syn på verden. En læsning af to bondedagboger, in: Fortid og Nutid 1994, p. 227-243; Karen Schousboe (ed.): Bondedagboger kilder til dagliglivets historie. Introduktion og registrant, Brede 1980.

40. Cf. Hilding Pleijel: Gamla utfärdstal från svenska bygder (=Meddelanden från kyrkohistoriska arkivet i Lund, vol. 11), Lund 1956.

41. Cf. Emil Weller: Die ersten deutschen Zeitungen. Mit einer Bibliographie (1505-1599)

(=Bibliothek des litterarischen Vereins in Stuttgart, vol. 111), Stuttgart 1872 (Repr. (with 
supplements) Hildesheim \& New York 1971); P[eter] M[atthias] Stolpe: Dagspressen i Danmark, dens Vilkaar og Personer indtil Midten af det attende Aarhundrede, vol. 1, Copenhagen 1878 (p. IXCIV: Bibliografisk Fortegnelse over danske Flyveblade); Fiskaa (cf. n. 23).

42. Cf. Michael Chesnutt: Folktale, in: Encyclopedia of Medieval Folklore (working title), New York: Garland 1998 (forthcoming).

43. Caspar Hennenberger: Erclerung der Preüssischen grössern Landtaffel ... Sampt vielen schönen auch Wunderbarlichen Historien ..., Königsberg 1595, index f. D4r: "Register ... nach ordnung der Zehen Gebot ... / zu nutz armen (sic) Pfarherrn / so die grossen Promptuaria Exemplorum nicht zu zalen haben".

44. Grethe Larsen \& Erik Dal: Danske Provinstryk 1482-1830. En bibliografi, vol. 1 sqq., Copenhagen 1994 sqq.; Henrik Horstbøll: De "små historier" og læserevolutionen i 1700-tallet, in: Fund og Forskning 33 (1994), p. 77-99; Hans Erich Bödeker (ed.): Histoires du livre, nouvelles orientations (=In Octavo, vol. 1), Paris 1995; Roger Chartier (ed.): Histoires de la lecture, un bilan des recherches (=In Octavo, vol. 2), Paris 1995.

45. Alfred Messerli: Propaganda und Ideologie der Schriftlichkeit in Deutschschweizer Volkskalendern, in: Schweizerisches Archiv für Volkskunde 88 (1992), p. 175-205, here p. 192 sq.

46. Jan de Vries: Nederlands etymologisch woordenboek, Leyden 1963-71, p. 599, s. v. sage: "De reden, dat in de $18 \mathrm{de}$ eeuw de duitse vorm opnieuw overgenomen werd, is dat het in het nieuwhoogduits de speciale betekenis gekregen had van 'bericht over gebeurtenissen in het verleden, die langs mondelinge weg overgeleverd zijn'. Een typisch woord van de romantiek"; Ordbok över svenska språket utgiven af Svenska Akademien, vol. 24, Lund 1965, col. S 104-127, s. v. saga, sagen; and comparable dictionaries.

47. Cf. also Waldemar Liungman: Das wahrscheinliche Alter des Volksmärchens in Schweden (=FF Communications, no. 156), Helsinki 1955.

48. I have earlier studied the dissemination of news and religious tracts around the Baltic Sea, cf. Jürgen Beyer: Lutherische Propheten in Deutschland und Skandinavien im 16. und 17. Jahrhundert. Entstehung und Ausbreitung eines Kulturmusters zwischen Mündlichkeit und Schriftlichkeit, in: Robert Bohn (ed.): Europa in Scandinavia. Kulturelle und soziale Dialoge in der frühen Neuzeit (=Studia septemtrionalia, vol. 2), Frankfort-on-the-Main 1994, p. 35-55; id.: George Reichard und Laurentius Matthæi: Schulmeister, Küster, Verfasser, Buchhändler und Verleger im letzten Jahrzehnt des Dreißigjährigen Krieges, in: Roger Chartier \& Alfred Messerli (eds.): Pratiques de lire - pratiques d'écrire en Europe, 1500-1900 (working title), Basle, Boston \& Berlin: Birkhäuser 1998 (forthcoming).

49. Cf. Ingrid Tomkowiak: Lesebuchgeschichten. Erzählstoffe in Schullesebüchern 1770-1920, Berlin \& New York 1993. 